\title{
ANALISIS KARAKTERISTIK HIDROLOGI SUNGAI GAJAHWONG DAERAH ISTIMEWA YOGYAKARTA
}

\author{
Supatno $^{1}$, Andrea Sumarah Asih ${ }^{2}$ \\ Jurusan Teknik Sipil \\ Sekolah Tinggi Teknologi Nasional \\ Jalan Babarsari, Catur Tunggal, Depok, Sleman, Yogyakarta \\ ${ }^{1}$ supatno@sttnas.ac.id
}

\begin{abstract}
Structuring and technical planning for the development of a watershed requires analysis of hydrological characteristics. This study aimed to analyze the hydrology characteristics of Gajahwong river to be formulated technical effort Gajahwong watershed development. Stages of analysis using secondary data from the Balai PSDA DIY Province, such as watershed maps, daily rain, rain hourly, daily discharge, discharge of flood and flood event records from 2001 to 2013. Analysis of peak flow / flood hydrograph using frequency analysis methods and Collins unit hydrograph methods. While the low-flow analysis using the model HSS Gama I and HS Gama II. The tools used are ArcView, frequency analysis program and Solver are contained in Microsoft Excel. Based on the analysis of the peak flow of the flood discharge of 20 annual plan obtained $332 \mathrm{~m}^{3} / \mathrm{s}$ happened in the 4 th hour. While based on a low-flow analysis it can be concluded that during the dry season are still available Gajahwong river flow is sufficient to meet the needs of well water for irrigation, fisheries and river tours.
\end{abstract}

Keywords: frequency analysis, unit hydrograph, flood discharge, the daily discharge

\begin{abstract}
Abstrak
Penataan dan perencanaan teknis bagi pengembangan suatu DAS memerlukan analisis karakteristik hidrologi. Penelitian ini bertujuan untuk menganalisis karakteristik hidrologi Sungai Gajahwong agar dapat dirumuskan upaya teknis pengembangan DAS Gajahwong. Tahapan analisis menggunakan data sekunder dari Balai PSDA Provinsi DIY, berupa peta DAS, hujan harian, hujan jam-jaman, debit harian, debit banjir dan catatan kejadian banjir mulai tahun 2001 sampai 2013. Analisis aliran puncak/hidrograf banjir menggunakan metode analisis frekuensi dan metode hidrograf satuan Collins. Sedangkan analisis aliran rendah menggunakan model HSS Gama I dan HS Gama II. Alat bantu yang digunakan adalah ArcView, program analisis frekuensi dan Solver yang terdapat dalam Microsoft Excel. Berdasarkan analisis aliran puncak didapatkan debit banjir rencana 20 tahunan sebesar 332 meter per detik yang terjadi pada jam ke-4. Sedangkan berdasar analisis aliran rendah dapat disimpulkan bahwa pada saat musim kemarau masih tersedia aliran sungai Gajahwong yang cukup untuk dapat memenuhi kebutuhan air baik untuk irigasi, perikanan maupun wisata sungai.
\end{abstract}

Kata kunci : analisis frekuensi, hidrograf satuan, debit banjir, debit harian 


\section{Pengantar}

Sungai Gajahwong merupakan satu dari tiga sungai besar yang membelah Kota Yogyakarta selain Sungai Code dan Sungai Winongo. Secara umum permasalahan yang ada di setiap sungai adalah sama yaitu permukiman ilegal yang mempersempit badan sungai, resiko bencana seperti banjir, tanah longsor, erupsi lahar dingin Merapi, sampah, dan limbah industri (JB. Satrio, 2013). Selain itu ketiga sungai juga harus menerima beban drainase yang besar mengingat konsep drainase di ketiga sungai tersebut masih mengacu pada konsep drainase konvensional (Hestin, 2011).

Penataan dan perencanaan teknis bagi pengembangan suatu DAS memerlukan analisis karakteristik hidrologi. Karena di Indonesia ada dua musim, musim hujan dan musim kemarau, maka analisis karakteristik hidrologi atau keberadaan air dilakukan berdasarkan tinjauan peak flow/aliran puncak dan low flow/aliran rendah. Peak flow pada waktu musim hujan dikaji dengan lebih menekankan pada kelebihan air yang bisa menjadi bencana banjir. Artinya peak flow dilakukan untuk pengelolaan banjir/flood management. Low flow lebih dominan untuk tinjauan ketersediaan air pada waktu musim kemarau (RJ. Kodoatie \& Roestam S, 2010).

Mengingat begitu pentingnya penataan lingkungan dan pengembangan DAS Gajahwong maka perlu dilakukan analisis karakteristik hidrologi Sungai Gajahwong. Hasil analisis karakteristik hidrologi yang berupa aliran puncak (debit banjir) dan aliran rendah (debit harian sungai) dapat menjadi informasi awal bagi perencanaan teknis dan penataan DAS Gajahwong. Dengan demikian fungsi dan manfaat sungai dapat tetap terjaga, penduduk yang tinggal di bantaran sungai terselamatkan, serta kelestarian lingkungan terjaga.

\subsection{Tinjauan Pustaka}

Di dalam analisis hidrologi, masukan hujan yang digunakan adalah curah hujan rerata DAS. Metode yang digunakan adalah metode Poligon Thiessen. Cara ini mengandaikan bobot tertentu kepada masing - masing setasiun hujan sebagai fungsi jarak antar setasiun (Rahmat, J., 2000).

Analisis frekuensi bertujuan memperkirakan besaran tinggi hujan dengan kala ulang tertentu dari hujan terukur dengan menggunakan cara statistik. Penyiapan data dilakukan dengan mengumpulkan data hujan DAS yang diperoleh dari stasiun yang ada, lalu dihitung hujan rata-rata harian sepanjang data tahunan yang tersedia. Setelah hujan rata-rata dihitung, 
kemudian dilakukan pemilihan seri data untuk analisis frekuensi dengan metode maximum annual series.

\subsection{Analisis Hidrograf Banjir Menggunakan Hidrograf Satuan}

Dalam perancangan bangunan air biasanya diperlukan data-data tentang banjir, terutama debit banjir. Untuk mengetahui debit banjir itu dilakukan analisis hidrograf banjir. Hidrograf banjir dapat diturunkan dengan Hidrograf satuan terukur dengan cara Collins (Sri Harto, 2000), dengan tahapan sebagai berikut.

a. Pilih kasus hujan atau rekaman AWLR (hidrograf tinggi muka air tunggal) yang terkait, dan tetapkan hidrografnya dengan liku kalibrasi yang berlaku.

b. Hidrograf limpasan langsung diperoleh dengan memisahkan aliran dasar dari hidrograf tersebut. Selanjutnya hujan efektif ditetapkan dengan indeks $\Phi$, sedemikian sehingga volume hujan mangkus sama dengan volume hidrograf limpasan langsung.

c. Hidrograf satuan hipotetik ditetapkan sembarang, akan tetapi hidrograf satuan hipotetik yang pasti ditetapkan dengan ordinat-ordinatnya.

d. Semua hujan yang terjadi, kecuali hujan yang maksimum ditransformasikan dengan hidrograf satuan hipotetik sehingga diperoleh sebuah hidrograf baru.

e. Apabila hidrograf terukur dikurangi oleh hidrograf yang diperoleh pada butir (d), maka yang akan diperoleh adalah hidrograf yang ditimbulkan oleh hujan maksimum. Dengan demikian, maka hidrograf satuan $1 \mathrm{~mm} / \mathrm{jam}$ baru dapat diperoleh dengan membagi semua ordinat hidrograf ini dengan intensitas hujan maksimum. Hidrograf satuan yang diperoleh terakhir ini dibandingkan dengan hidrograf satuan hipotetik. Jika perbedaannya cukup besar dari patokan yang telah ditetapkan, maka butir (d) diulangi lagi dengan menggunakan hidrograf satuan yang diperoleh dari butir (e).

f. Lakukan prosedur ini berulang-ulang sehingga diperoleh sebuah hidrograf satuan yang tidak berbeda banyak dari yang ditetapkan.

\subsection{Model HSS Gama I}

Transformasi hujan menjadi aliran yang digunakan dalam HSS Gama I mengikuti andaian, bahwa hujan yang jatuh di dalam DAS akan mengalir pertama sekali melewati sungai-sungai tingkat I (satu), yang selanjutnya mengalir ke sungai-sungai dengan tingkat yang lebih tinggi, sampai akhirnya sampai ke titik kontrol (titik yang ditinjau).

HSS Gama I terdiri dari empat variabel pokok yaitu waktu naik (Time Of Rise, TR), debit puncak (Peak Of discharge, QP), waktu Dasar (Time of base, TB) dan koefisien tampungan (Storage Coefficient, K). 


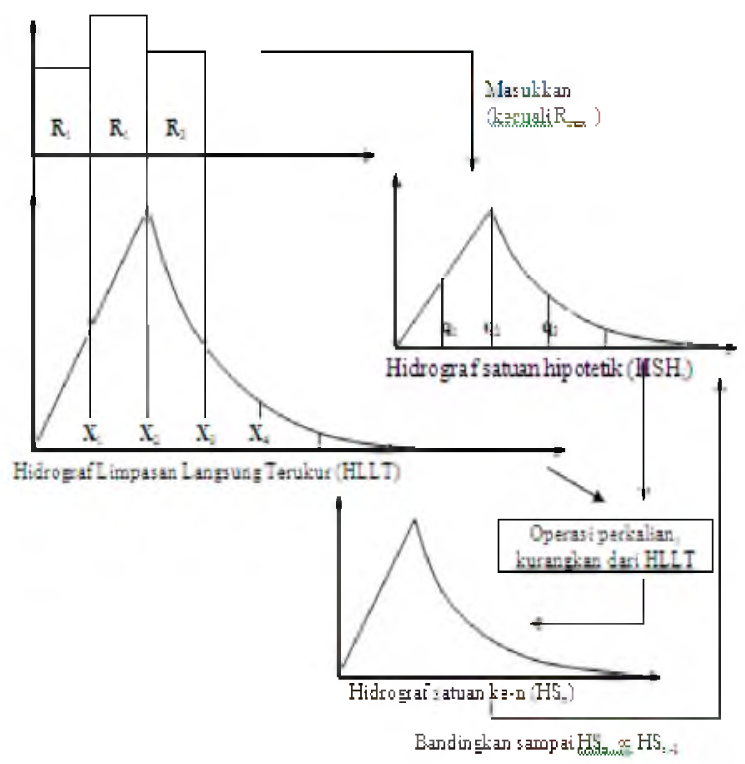

Gambar 1. Urutan cara Collins

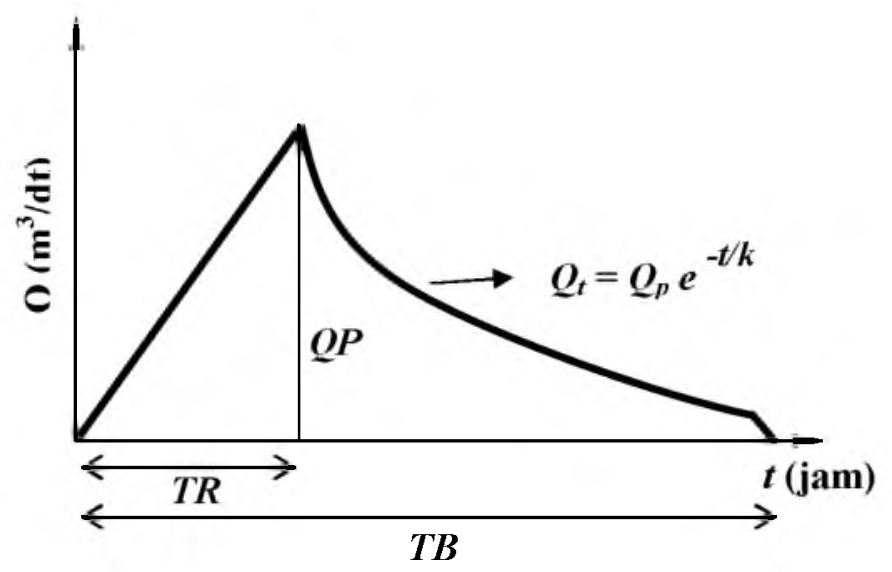

Gambar 2. Hidrograf satuan sintetik Gama I

\subsection{Model HS Gama II}

HSS Gama I hanya dapat digunakan untuk memperkirakan besaran hidrograf untuk besaran hujan tertentu (event model). Untuk dapat mewakili sifat hidrograf selama tidak ada hujan diperlukan persamaan sisi resesi dengan koefisien tampungan yang berbeda. Penggabungan antara konsep HSS Gama I dan persamaan aliran dasar ini melahirkan konsep baru, Hidrograf Sintetik Gama II (Sri Harto, 1990) yang dirumuskan dalam persamaan berikut ini.

$$
\mathrm{Kg}_{2}=100\left(16,5395+0,6578 \mathrm{~F}^{7}-17,0379 \mathrm{SN}-1,911 \mathrm{D}\right)^{0.5}
$$

dengan : 


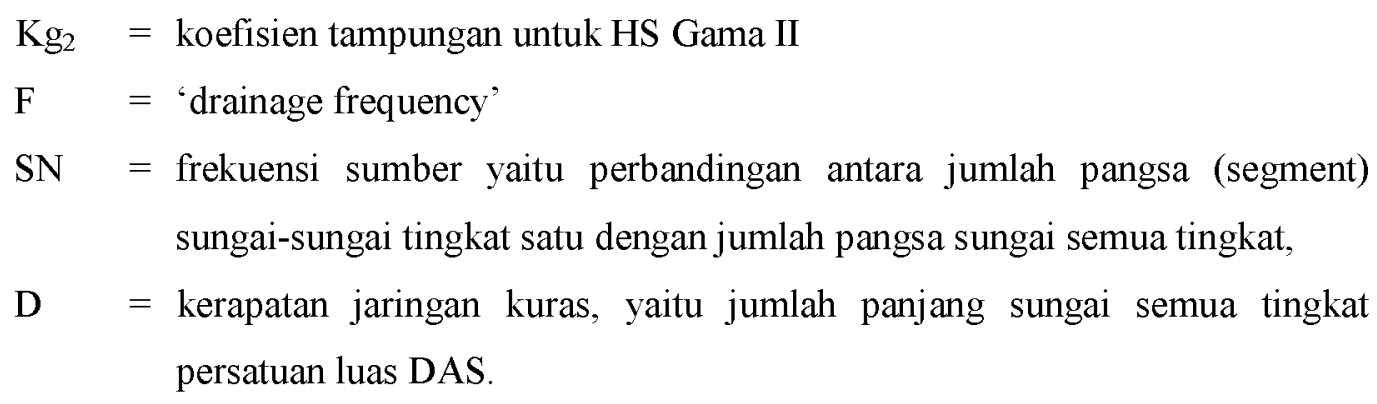

Dengan demikian penggabungan kedua rumusan HSS Gama I dan HS Gama II dapat mewakili aliran sungai baik pada saat terjadi hujan maupun saat tidak terjadi hujan (cumulatife flow). Dari rumusan HSS Gama I dapat dilihat bahwa variabel yang tidak menentu adalah variabel kehilangan air (phi indeks), meskipun dalam penurunan HSS Gama I telah diberikan besaran perkiraannya. Besaran variabel tersebut juga merupakan satusatunya variabel yang perlu ditetapkan terlebih dulu sebelum HS Gama II dapat dioperasikan. Oleh sebab itu HS Gama II masih memerlukan tahap kalibrasi untuk menetapkan besaran phi tersebut.

\section{Metode Penelitian}

Pada penelitian ini metode yang dipakai adalah Deskriptif Evaluatif, yaitu metode penelitian yang mengevaluasi kondisi obyektif/apa adanya pada suatu keadaan yang sedang menjadi obyek studi (Supriharyono, 2002). Obyek studi yang dimaksud adalah pengembangan kawasan DAS Gajahwong yang memiliki fungsi dan manfaat baik dari segi ekonomi, wisata maupun budaya. Pengembangan kawasan DAS Gajahwong diawali dengan analisis karakteristik hidrologi berupa debit puncak di musim penghujan dan debit harian di musim kemarau.

\subsection{Rancangan Penelitian}

\section{A. Kebutuhan Data}

Data yang diperlukan dalam pengembangan kawasan DAS Gajahwong berdasarkan tinjauan karakteristik hidrologi berupa data sekunder maupun data primer. Data-data tersebut meliputi :

- data topografi meliputi lokasi DAS Gajahwong serta batas-batas administrasi

- data iklim dan hidrologi berupa data hujan harian maupun jam-jaman dengan panjang data minimal 10 tahun pada beberapa stasiun penakar hujan DAS dimaksud 
- data debit aliran sungai

- data debit banjir dan catatan kejadian banjir

\section{B. Teknik Pengumpulan Data}

Dalam penjelasan mengenai kebutuhan data dijelaskan bahwa jenis data yang dibutuhkan dalam penelitian ini adalah data primer dan sekunder. Untuk memperoleh data tersebut, beberapa teknik pengumpulan data yang akan dilakukan dalam studi ini adalah sebagai berikut:

1. Studi literatur, untuk memperoleh landasaan teoritik mengenai pengembangan kawasan DAS, selain itu studi literatur juga dilakukan untuk memperoleh gambaran awal mengenai kondisi eksisting wilayah studi.

2. Dokumentasi, merupakan teknik pengumpulan data melalui sumber-sumber data sekunder. Teknik ini dilakukan dengan cara mencatat dan mempelajari data yang telah tersedia. Teknik dokumentasi ini akan dilakukan di beberapa instansi, antara lain Pemda, Bappeda, Dinas PU, Departemen Kimpraswil dan instansi terkait lainnya.

3. Observasi dan Pengukuran Lapangan, merupakan teknik pengumpulan data dengan cara turun langsung ke lapangan, untuk mengetahui lokasi, elevasi permukaan, batas-batas administrasi dan pola aliran yang ada.

\section{Proses Analisis Data}

Proses analisis yang akan dilakukan meliputi tiga tahapan, yaitu Input-Analisis-Output. Input tahapan penelitian ini didapatkan dari analisis hasil survey dan observasi yang berupa data hujan maksimum, data kejadian banjir serta potensi pengembangan wilayah DAS Gajahwong. Data-data tersebut selanjutnya dianalisis dalam dua tahapan yaitu analisis hidologi dan analisis hidrolika.

Tahapan analisis hidrologi diawali dengan menganalisis data hujan dari beberapa stasiun penakar hujan untuk menentukan hujan harian maksimum rerata yang selanjutnya dianalisis frekuensi untuk menentukan besar hujan rancangan. Menggunakan metode hidrograf satuan, data hujan rancangan selanjutnya dianalisis sehingga didapatkan hidrograf banjir DAS Gajahwong untuk kala ulang tertentu. Data debit harian dianalisis menggunakan metode HSS Gama I dan HS Gama II untuk memperoleh prediksi debit harian.

Setelah didapatkan perkiraan besar debit banjir dan debit harian, analisis hidrolika diperlukan untuk dapat menentukan pemilihan konstruksi maupun upaya teknis yang diperlukan, misalnya berupa pembangunan tanggul, talud ataupun upaya teknis lainnya. Adapun alat bantu yang digunakan untuk keperluan analisis hidrologi dan hidraulika dalam 
penelitian ini adalah program analisis frekuensi dalam bentuk Microsoft Excel, software ArcGIS dan HEC-RAS.

\section{Hasil dan Pembahasan}

\subsection{Analisis Aliran Puncak (Debit Banjir Sungai)}

Berdasarkan data kejadian banjir yang diperoleh disimpulkan ada beberapa kejadian banjir ekstrim yang terjadi yaitu di tahun 2004, 2012 dan 2013. Dari ketiga kejadian banjir tersebut dipilih data banjir terbesar yaitu kejadian banjir tanggal 17 Januari 2012.

Tahapan analisis frekuensi diawali dengan pemilihan seri data hujan maksimum harian yang dilakukan berdasarkan metode annual maximum series, yaitu mengambil hujan harian yang terbesar setiap tahunnya pada stasiun hujan yang dipilih.

Setelah didapatkan hasil nilai tinggi hujan maksimum, tahapan dilanjutkan dengan analisis untuk mengetahui jenis distribusi statistik yang cocok dalam penentuan besar hujan dengan kala ulang tertentu. Dalam hal ini, dilakukan uji Chi Square dan uji SmirnovKolmogorov. Berdasarkan hasil pengujian menggunakan program Analisis Frekuensi dengan bantuan software Excel Visual Basic For Application (Kurniawan, 1998) didapatkan distribusi statistik yang cocok adalah distribusi log normal.

Berikut ini adalah hasil analisis hujan rancangan dengan kala ulang yang telah ditetapkan pada sub DAS Gajahwong yang disajikan pada berikut ini.

Tabel 1. Hujan rancangan berbagai kala ulang.

\begin{tabular}{|c|c|}
\hline Kala Ulang Hujan & Hujan Rancangan $(\mathrm{mm})$ \\
\hline 5 & 73,6 \\
\hline 10 & 88,89 \\
\hline 20 & 104,39 \\
\hline 50 & 125,67 \\
\hline 100 & 142,66 \\
\hline
\end{tabular}

Dalam penelitian ini hanya dianalisis besar hujan rancangan dengan kala ulang 20 tahun yaitu sebesar $104,39 \mathrm{~mm}$.

\subsubsection{Analisis Hidrograf Satuan Terukur}

Analisis hidrograf satuan terukur dilakukan dengan cara Collins berdasarkan kejadian banjir pada tanggal 17-18 Januari 2012. Data yang tersedia di Balai PSDA berupa rekaman AWLR (hidrograf tinggi muka air) yang harus ditetapkan hidrografnya dengan liku kalibrasi yang berlaku pada DAS Gajahwong di Papringan yaitu sebesar $\mathrm{Q}=9,5^{*}(\mathrm{H}-0)^{\wedge} 2,19$. Analisis 
tinggi muka air tersebut digabungkan dengan analisis hujan rerata DAS Gajahwong untuk mendapatkan hidrograf limpasan langsung.

Analisis hidrograf limpasan langsung diperoleh dengan memisahkan aliran dasar dari hidrograf tersebut. Selanjutnya hujan efektif ditetapkan dengan indeks $\Phi$, sedemikian sehingga volume hujan mangkus sama dengan volume hidrograf limpasan langsung.

Tabel 2. Hidrograf Satuan DAS Gajahwong di Papringan, 17-18 Januari 2012

\begin{tabular}{|c|c|c|c|c|c|c|c|c|c|c|}
\hline \multirow[t]{2}{*}{$\begin{array}{l}\text { Jam } \\
\text { ke- }\end{array}$} & $\mathrm{t}$ & $\begin{array}{l}\text { Muka } \\
\text { air }\end{array}$ & $Q$ & $\mathrm{QBF}_{\mathrm{BF}}$ & HLL & $\mathrm{R}$ & \multirow{2}{*}{$\begin{array}{c}\text { phi } \\
(\mathrm{mm})\end{array}$} & $P$ efl & Pef2 & \multirow{2}{*}{$\begin{array}{c}\mathrm{HS} \\
\left(\mathrm{m}^{3} / \mathrm{s}\right)\end{array}$} \\
\hline & (jam) & $\mathrm{H}(\mathrm{m})$ & $\left(\mathrm{m}^{3} / \mathrm{s}\right)$ & $\left(\mathrm{m}^{3} / \mathrm{s}\right)$ & $\begin{array}{l}(\mathrm{Q}- \\
\left.\mathrm{Q}_{\mathrm{BF}}\right)\end{array}$ & $(\mathrm{mm})$ & & 12.671 & 2.295 & \\
\hline 13 & 0 & 0.49 & 1.99 & 1.99 & 0.00 & 15.908 & 3.237 & 0.00 & & 0.00 \\
\hline 14 & 1 & 0.5 & 2.08 & 2.04 & 0.04 & 5.532 & & 0.04 & 0.00 & 0.00 \\
\hline 15 & 2 & 0.84 & 6.48 & 2.09 & 4.40 & 0.676 & & 4.39 & 0.01 & 0.35 \\
\hline 16 & 3 & 2.39 & 64.03 & 2.13 & 61.90 & 0.36 & & 61.11 & 0.80 & 4.82 \\
\hline 17 & 4 & 1.94 & 40.55 & 2.18 & 38.37 & 0.512 & & 27.30 & 11.07 & 2.15 \\
\hline 18 & 5 & 1.34 & 18.03 & 2.23 & 15.81 & 0.008 & & 10.86 & 4.95 & 0.86 \\
\hline 19 & 6 & 1.06 & 10.79 & 2.27 & 8.52 & & & 6.55 & 1.97 & 0.52 \\
\hline 20 & 7 & 1 & 9.50 & 2.32 & 7.18 & & & 5.99 & 1.19 & 0.47 \\
\hline 21 & 8 & 0.93 & 8.10 & 2.37 & 5.74 & & & 4.65 & 1.09 & 0.37 \\
\hline 22 & 9 & 0.88 & 7.18 & 2.41 & 4.77 & & & 3.92 & 0.84 & 0.31 \\
\hline 23 & 10 & 0.85 & 6.66 & 2.46 & 4.19 & & & 3.48 & 0.71 & 0.27 \\
\hline 24 & 11 & 0.81 & 5.99 & 2.51 & 3.48 & & & 2.85 & 0.63 & 0.22 \\
\hline 1 & 12 & 0.8 & 5.83 & 2.55 & 3.27 & & & 2.76 & 0.52 & 0.22 \\
\hline 2 & 13 & 0.77 & 5.36 & 2.60 & 2.76 & & & 2.26 & 0.50 & 0.18 \\
\hline 3 & 14 & 0.76 & 5.21 & 2.65 & 2.56 & & & 2.15 & 0.41 & 0.17 \\
\hline 4 & 15 & 0.75 & 5.06 & 2.69 & 2.37 & & & 1.98 & 0.39 & 0.16 \\
\hline 5 & 16 & 0.73 & 4.77 & 2.74 & 2.03 & & & 1.67 & 0.36 & 0.13 \\
\hline 6 & 17 & 0.72 & 4.63 & 2.79 & 1.84 & & & 1.54 & 0.30 & 0.12 \\
\hline 7 & 18 & 0.70 & 4.35 & 2.83 & 1.52 & & & 1.24 & 0.28 & 0.10 \\
\hline 8 & 19 & 0.58 & 2.88 & 2.88 & 0.00 & & & -0.22 & 0.22 & -0.02 \\
\hline
\end{tabular}

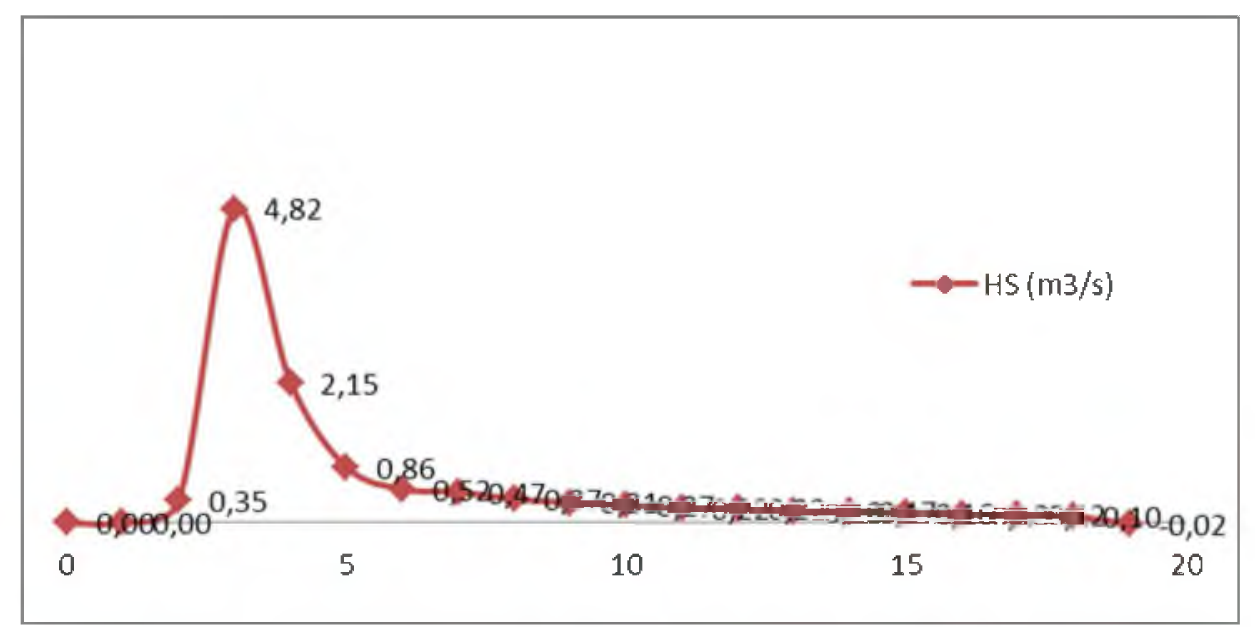

Gambar 3. Hidrograf Satuan DAS Gajahwong di Papringan, 17-18 Januari 2012 


\subsubsection{Analisis Hidrograf Banjir 20 Tahunan}

Selanjutnya analisis hidrograf banjir rancangan dapat diperoleh setelah hidrograf satuan Collins dikalikan dengan hujan efektif untuk mendapatkan hidrograf limpasan langsung. Dari analisis ini pada akhirnya dapat diprediksi menjadi hidrograf banjir rancangan untuk kala ulang 20 tahunan.

Dari analisis hidrograf banjir 20 tahunan didapatkan debit puncak sebesar $332 \mathrm{~m}^{3} / \mathrm{s}$ pada jam ke-4 dengan perincian hitungan seperti terdapat pada tabel dan gambar hidrograf banjir berikut ini.

Tabel 3. Hidrograf Banjir Sungai Gajahwong dengan kala ulang 20 tahunan

\begin{tabular}{|c|c|c|c|c|c|c|c|c|c|c|}
\hline \multirow[t]{2}{*}{$\mathrm{T}$} & \multirow{2}{*}{$\begin{array}{c}\mathrm{R}_{20} \\
\text { th } \\
(\mathrm{mm})\end{array}$} & \multirow{2}{*}{$\begin{array}{l}\text { phi } \\
\text { rerata } \\
(\mathrm{mm})\end{array}$} & \multirow{2}{*}{$\begin{array}{c}\text { P } \\
\text { efektif } \\
(\mathrm{mm})\end{array}$} & \multirow{2}{*}{$\begin{array}{c}\mathrm{HS} \\
\text { rerata } \\
\left(\mathrm{m}^{3} / \mathrm{s}\right)\end{array}$} & \multicolumn{4}{|c|}{ Akibat hujan } & \multirow{2}{*}{$\begin{array}{l}\text { QBF } \\
\left(\mathrm{m}^{3} / \mathrm{s}\right)\end{array}$} & \multirow{2}{*}{$\begin{array}{c}\mathrm{Q} \\
\left(\mathrm{m}^{3} / \mathrm{s}\right. \\
)\end{array}$} \\
\hline & & & & & $\begin{array}{c}39,94 \\
2\end{array}$ & $\begin{array}{c}25,38 \\
4\end{array}$ & 16,721 & $\begin{array}{c}11,68 \\
5\end{array}$ & & \\
\hline 1 & 42,61 & 2,66 & 39,94 & 0,00 & 0 & & & & 1,29 & 1 \\
\hline 2 & 28,05 & & 25,38 & 0,00 & 0 & 0 & & & 1,32 & 2 \\
\hline 3 & 19,39 & & 16,72 & 0,20 & 8 & 0 & 0 & & 1,35 & 9 \\
\hline 4 & 14,35 & & 11,69 & 8,15 & 325 & 5 & 0 & 0 & 1,39 & 332 \\
\hline 5 & & & & 1,70 & 68 & 207 & 3 & 0 & 1,42 & 280 \\
\hline 6 & & & & 0,72 & 29 & 43 & 136 & 2 & 1,45 & 212 \\
\hline 7 & & & & 0,46 & 18 & 18 & 28 & 95 & 1,48 & 162 \\
\hline 8 & & & & 0,49 & 19 & 12 & 12 & 20 & 1,52 & 65 \\
\hline 9 & & & & 0,30 & 12 & 12 & 8 & 8 & 1,55 & 42 \\
\hline 10 & & & & 0,30 & 12 & 7 & 8 & 5 & 1,58 & 34 \\
\hline \multirow[t]{2}{*}{$\mathrm{T}$} & $\begin{array}{c}\mathrm{R}_{20} \\
\text { th }\end{array}$ & $\begin{array}{c}\text { phi } \\
\text { rerata }\end{array}$ & $\begin{array}{c}\text { P } \\
\text { efektif }\end{array}$ & $\begin{array}{c}\mathrm{HS} \\
\text { rerata }\end{array}$ & \multicolumn{4}{|c|}{ Akibat hujan } & \multirow{2}{*}{ QBF } & \multirow[b]{2}{*}{$(\mathrm{mm})$} \\
\hline & $(\mathrm{mm})$ & $(\mathrm{mm})$ & $(\mathrm{mm})$ & $\left(\mathrm{m}^{3} / \mathrm{s}\right)$ & $\begin{array}{c}39,94 \\
2 \\
\end{array}$ & $\begin{array}{c}25,38 \\
4 \\
\end{array}$ & 16,721 & $\begin{array}{c}11,68 \\
5\end{array}$ & & \\
\hline 11 & & & & 0,22 & 9 & 8 & 5 & 6 & 1,62 & 28 \\
\hline 12 & & & & 0,20 & 8 & 5 & 5 & 3 & 1,65 & 24 \\
\hline 13 & & & & 0,17 & 7 & 5 & 4 & 3 & 1,68 & 20 \\
\hline 14 & & & & 0,17 & 7 & 4 & 3 & 3 & 1,71 & 19 \\
\hline 15 & & & & 0,11 & 4 & 4 & 3 & 2 & 1,75 & 16 \\
\hline 16 & & & & 0,13 & 5 & 3 & 3 & 2 & 1,78 & 15 \\
\hline 17 & & & & 0,11 & 4 & 3 & 2 & 2 & 1,81 & 13 \\
\hline 18 & & & & 0,09 & 4 & 3 & 2 & 1 & 1,84 & 12 \\
\hline 19 & & & & 0,07 & 3 & 2 & 2 & 2 & 1,88 & 11 \\
\hline 20 & & & & 0,00 & 0 & 2 & 2 & 1 & 1,91 & 6 \\
\hline 21 & & & & 0,00 & 0 & 0 & 1 & 1 & 0,48 & 3 \\
\hline 22 & & & & 0,00 & 0 & 0 & 0 & 1 & 0,49 & 1 \\
\hline 23 & & & & 0,00 & 0 & 0 & 0 & 0 & 0,50 & 1 \\
\hline 24 & & & & 0,00 & 0 & 0 & 0 & 0 & 0,51 & 1 \\
\hline 25 & & & & & & 0 & 0 & 0 & 0,00 & 0 \\
\hline 26 & & & & & & & 0 & 0 & 0,00 & 0 \\
\hline
\end{tabular}




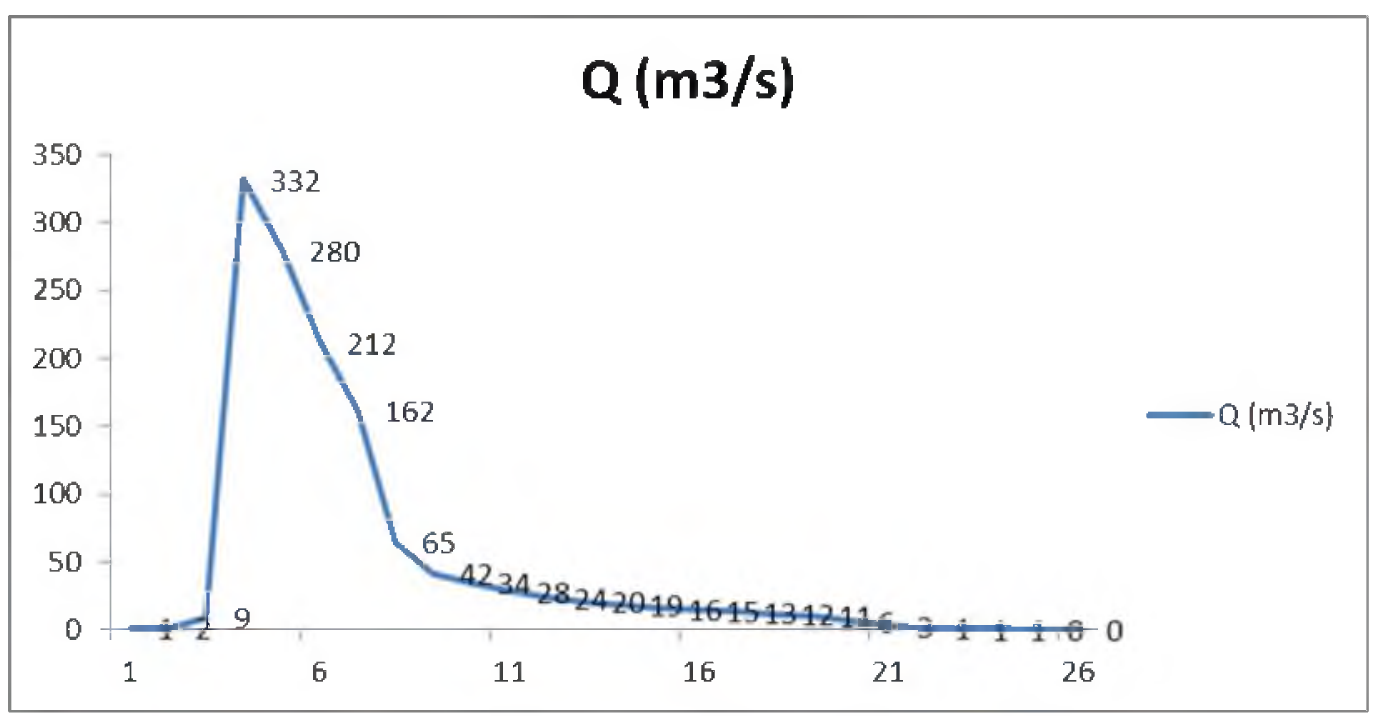

Gambar 4. Hidrograf Banjir Sungai Gajahwong dengan kala ulang 20 tahunan

\subsubsection{Analisis Aliran Rendah (Debit Harian Sungai)}

\section{A. Analisis Hidrograf Satuan Sintetik (HSS) Gama I}

Tahap awal analisis HSS Gama I adalah melakukan analisis peta DAS. Data topografi (peta DAS) yang diperoleh dari Balai PSDA Provinsi DIY selanjutnya dianalisis dengan menggunakan bantuan software ArcView GIS versi 3.2. Hasil analisis peta DAS ini berupa data morphometri (parameter-parameter) DAS yang diperlukan sebagai input model HSS Gama I.

Tabel 4. Parameter DAS hasil analisis ArcView

\begin{tabular}{|l|c|c|c|}
\hline \multicolumn{1}{|c|}{ Parameter } & Notasi & Nilai & Satuan \\
\hline Luas DAS & A & 48.77 & $\mathrm{~km}^{2}$ \\
Luas DAS sebelah hulu & RUA & 20.84 & $\mathrm{~km}^{2}$ \\
Lebar DAS 3/4 L & WU & 0.28 & $\mathrm{~km}$ \\
Lebar DAS 1/4 L & WL & 3.43 & $\mathrm{~km}$ \\
Slope sungai & $\mathrm{S}$ & 0.01 & - \\
Panjang sungai utama & & 35.92 & $\mathrm{~km}$ \\
Panjang sungai semua tingkat & & 62.04 & $\mathrm{~km}$ \\
Panjang sungai tingkat satu & & 25.35 & $\mathrm{~km}$ \\
Jumlah pertemuan sungai & & 10.00 & - \\
Pangsa sungai semua tingkat & & 20.00 & - \\
Pangsa sungai tingkat satu & & 11.00 & - \\
\hline
\end{tabular}


Berdasarkan parameter-parameter DAS yang diperoleh, maka analisis dilanjutkan dengan perhitungan hidrograf satuan menggunakan HSS Gama I sebagai dasar perhitungan HS Gama II. Perhitungan beberapa variabel dalam HSS Gama I disajikan dalam tabel berikut ini.

Tabel 5. Perhitungan variabel HSS Gama I

\begin{tabular}{|l|c|c|c|}
\hline \multicolumn{1}{|c|}{ Variabel } & Notasi & Nilai & Satuan \\
\hline Waktu puncak & TR & 1.61 & jam \\
Debit puncak & QP & 2.59 & $\mathrm{~m}^{3} / \mathrm{dt}$ \\
Waktu dasar & TB & 23.33 & jam \\
Koefisien Tampungan & K & 5.44 & jam \\
Phi indeks & $\varphi$ & 10.48 & - \\
Aliran dasar & QB & 3.14 & $\mathrm{~m}^{3} / \mathrm{dt}$ \\
\hline
\end{tabular}

\section{B. Analisis HS Gama II}

Besaran yang sangat berpengaruh dan harus ditentukan terlebih dahulu sebelum perhitungan HS Gama II adalah variabel kehilangan air (phi index). Besaran phi ini merupakan besaran yang variabel (temporarely variable) sehingga ditetapkan berdasar sifat aliran bulanan. Selain itu besaran yang juga berubah adalah koefisien tampungan. Setelah dilakukan analisa pada tahap kalibrasi untuk semua DAS ternyata jika dalam perhitungan aliran dasar digunakan nilai phi index dan koefisien tampungan Gama II ( $\left.\mathrm{Kg}_{2}\right)$ maka nilai phi index yang dihasilkan rata-rata kurang dari satu. Hal ini dianggap kurang riil sehingga kemudian aliran dasar diperhitungkan dengan nilai phi index dan $\mathrm{Kg}_{2}$ yang berbeda.

Perubahan ini dimungkinkan mengingat kondisi DAS di pulau Jawa pada saat ini telah banyak berubah. Besaran phi index dan koefisien tampungan Gama II ini ditetapkan secara sembarang dan harus dikalibrasi terhadap jumlah aliran kumulatif tahunan. Bila perbedaan nilai yang terjadi melebihi besaran yang ditetapkan (error criteria), maka hitungan diulang dengan mengubah nilai index phi dan $\mathrm{Kg}_{2}$. Kedua parameter tersebut dikalibrasi dengan menggunakan software SOLVER yang terdapat dalam microsoft excel. Sebagai objective function adalah nilai minimum root mean square dan volume error.

Sangat disayangkan data hujan otomatis (jam-jaman) yang dapat dikumpulkan pada DAS Gajahwong adalah sepanjang 10 tahun mulai tahun 1996 sampai dengan 2005. Sedangkan data hujan manual (harian) yang tersedia sampai tahun 2012 hanya dapat digunakan untuk analisis aliran puncak. Untuk proses kalibrasi digunakan data hujan maupun debit mulai tahun 1996 sampai dengan tahun 2000 dan tahapan verifikasi menggunakan data 
lima tahun berikutnya yaitu data hujan dan debit tahun 2000 dan 2005 . Hasil kalibrasi dan verifikasi DAS Gajahwong dengan bantuan SOLVER dapat dilihat pada gambar berikut.

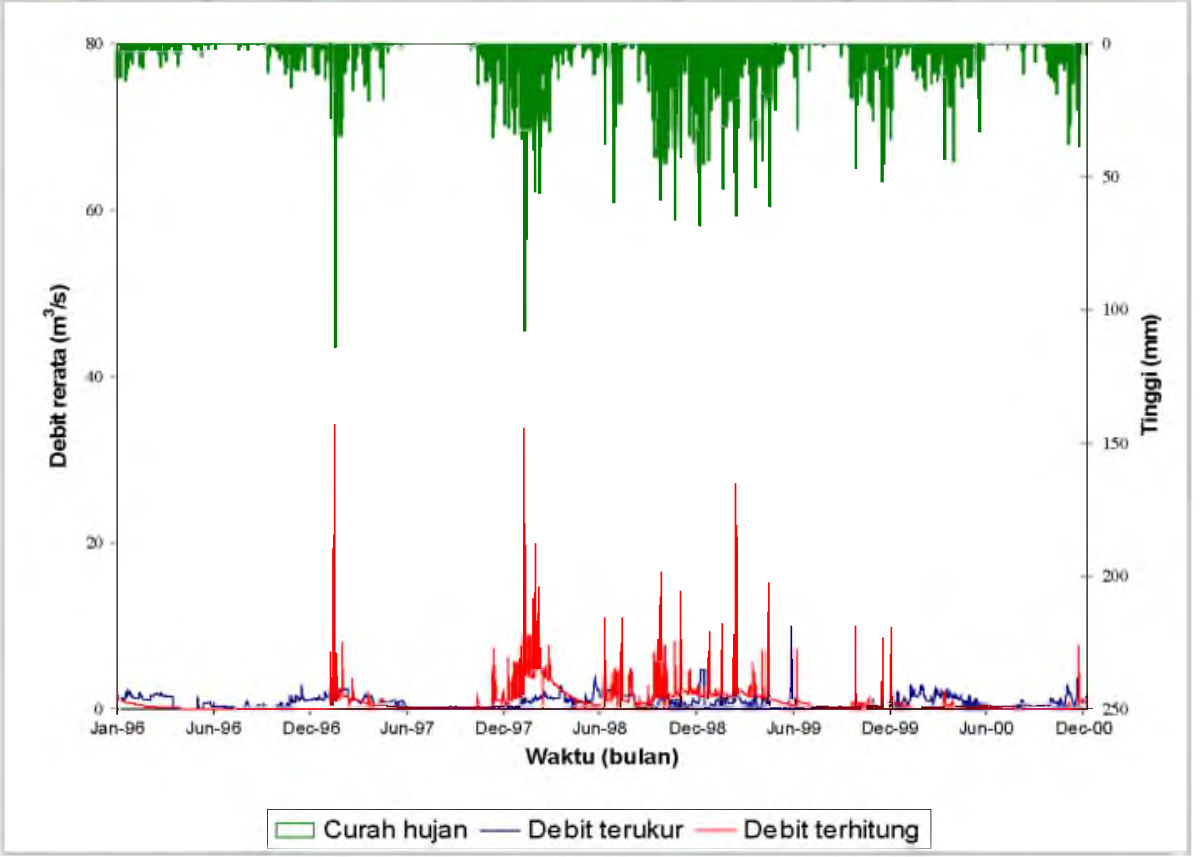

Gambar 5. Hidrograf hasil kalibrasi

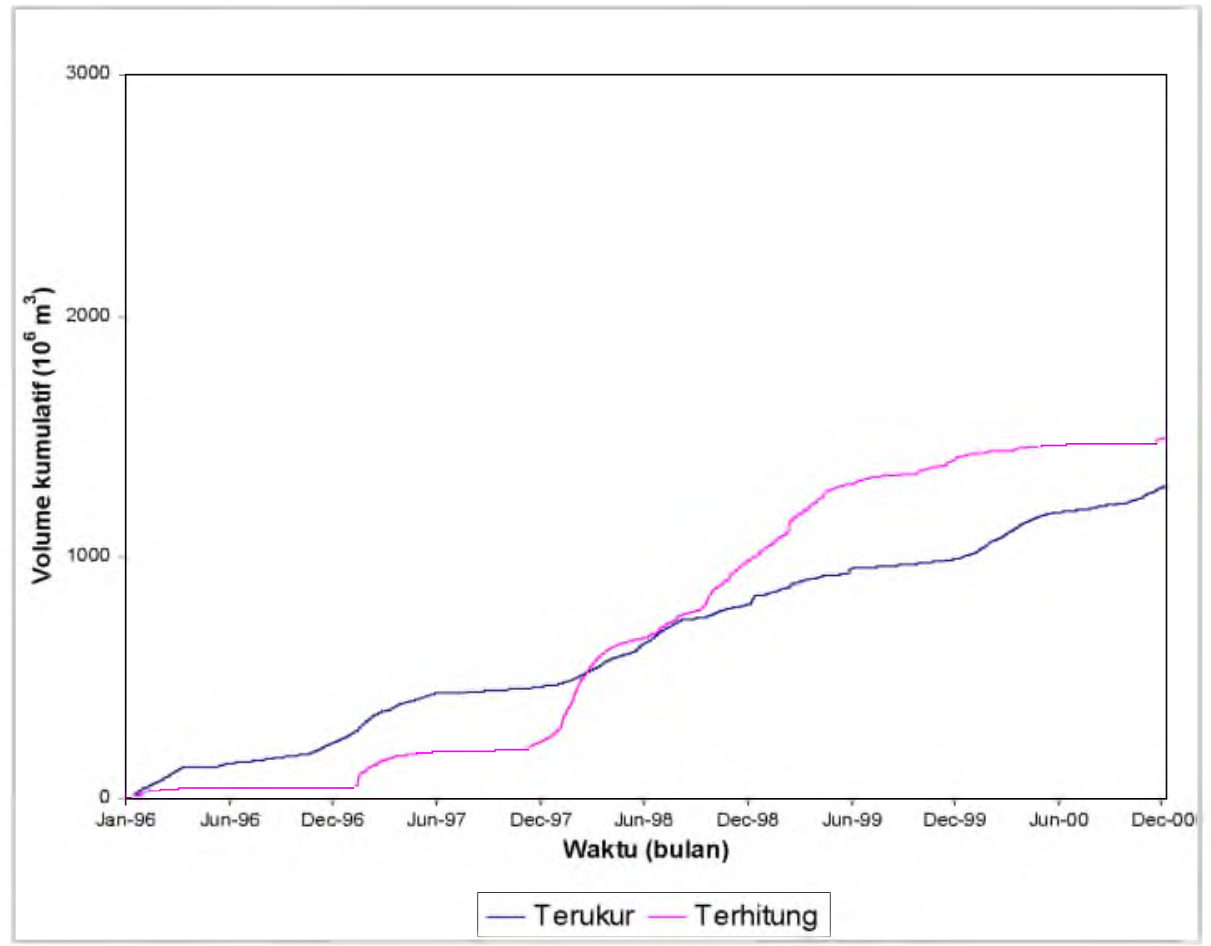

Gambar 6. Kalibrasi HS Gama II 


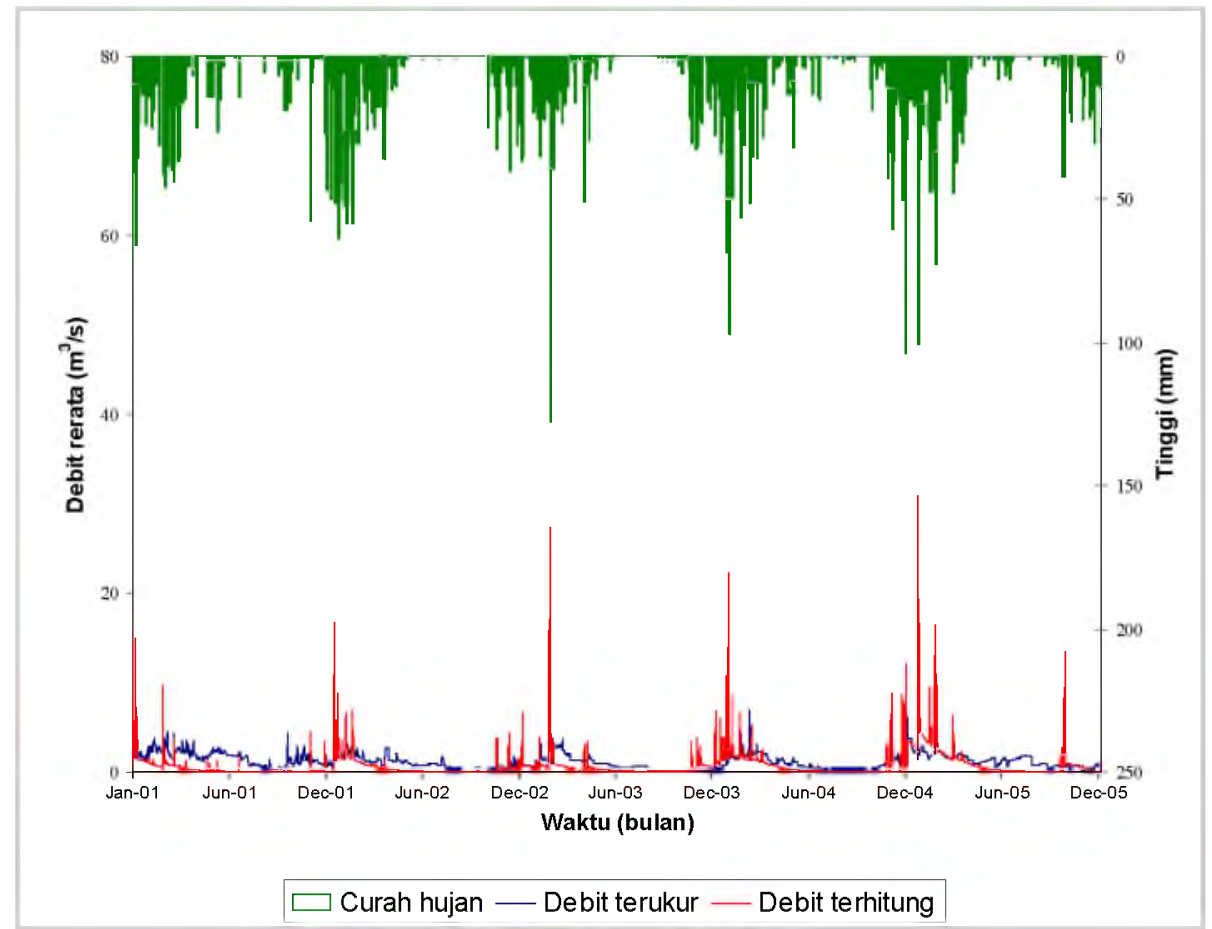

Gambar 7. Hidrograf hasil verifikasi

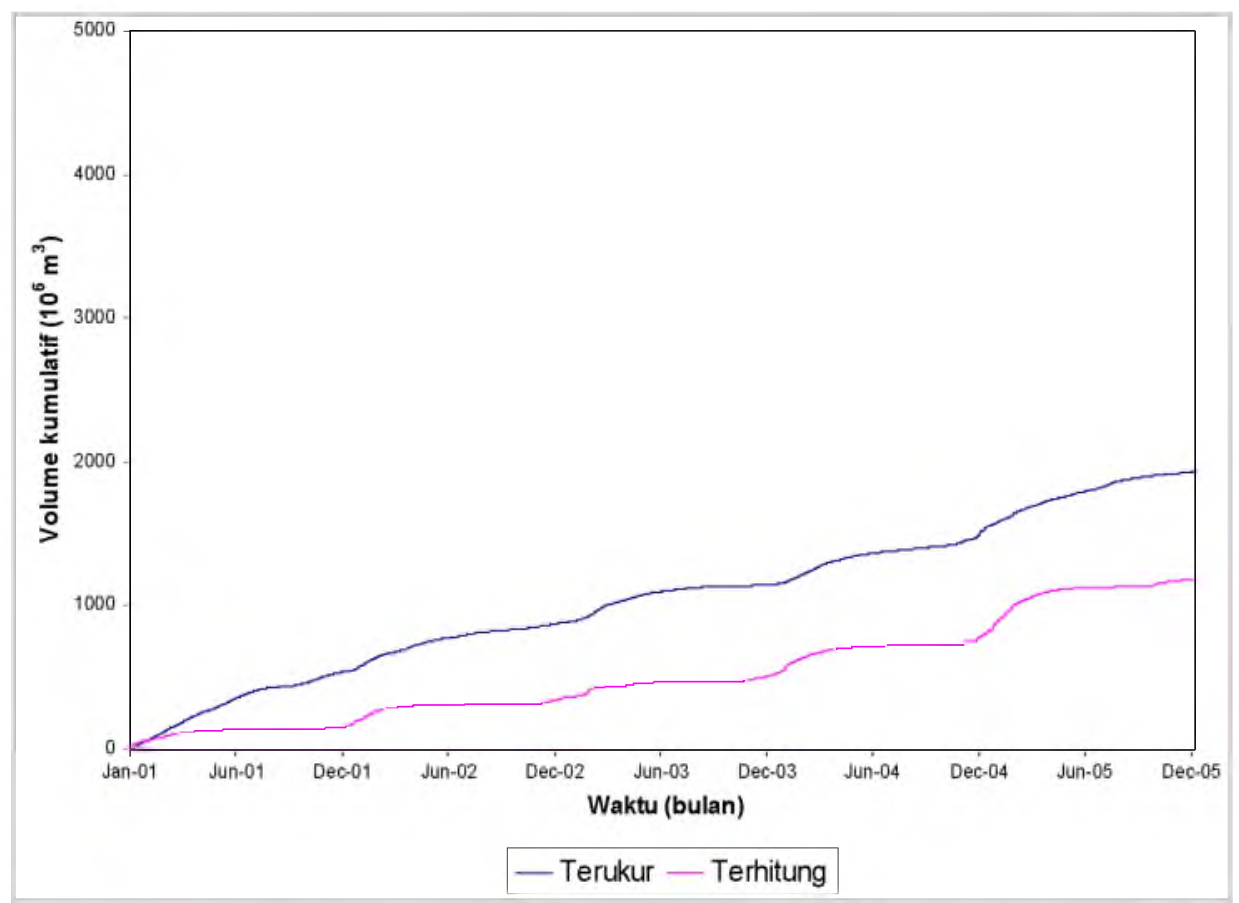

Gambar 8. Verifikasi HS Gama II 


\subsection{Pembahasan}

Dari Gambar 5 terlihat bahwa aliran kumulatif terhitung pada DAS Gajahwong menunjukkan penyimpangan yang relatif besar. Pada dua tahun pertama pengamatan mulai awal tahun 1996 sampai akhir tahun 1997 underestimated , 6 bulan berikutnya sama tetapi periode berikutnya sampai akhir tahun 2000 cenderung overestimated.

Meskipun demikian tingkat ketelitian model HS Gama II masih memenuhi ketentuan dimana nilai RMS dan VE yang dihasilkan masih relatif kecil yaitu sebesar 2,5712 dan $15,5392 \%$. Hal ini dimungkinkan karena perbedaan yang cukup signifikan antara besaran nilai hujan dengan nilai debit yang terukur sehingga kemungkinan hujan yang sebenarnya terjadi dalam DAS tidak sesuai dengan hujan yang digunakan untuk simulasi.

Hasil simulasi pada tahap verifikasi menunjukkan kecenderungan undrerestimated dengan nilai volume error yang cukup besar tetapi masih dibawah $50 \%$, dimana aliran yang terjadi tiap tahunnya rata-rata pada 3 bulan pertama baik, baru di bulan berikutnya underestimated sampai akhir tahun.

Berdasarkan analisis aliran puncak (debit banjir sungai) menggunakan hidrograf satuan Collins didapatkan debit banjir rencana dengan kala ulang 20 tahunan sebesar $332 \mathrm{~m}^{3} / \mathrm{s}$ yang terjadi pada jam ke-4. Nilai besaran debit banjir tersebut dapat menjadi informasi awal bagi perencanaan bangunan-bangunan hidrolik. Akan tetapi perlu diketahui terlebih dahulu kondisi eksisting penampang Sungai Gajahwong pada beberapa titik, misalnya di hulu, tengah maupun hilir. Untuk itu diperlukan observasi yang detail dan mendalam. Mengingat terbatasnya waktu dalam penelitian ini, tahapan analisis hidrolika tersebut belum dapat dilakukan. Akan lebih bermanfaat apabila penelitian ini kemudian dilanjutkan dengan penelitian berikutnya.

\section{Kesimpulan}

Memperhatikan hasil penelitian dan pembahasan yang telah diuraikan dalam bab terdahulu, dapat diambil kesimpulan sebagai berikut ini.

1. Berdasarkan analisis aliran puncak menggunakan hidrograf satuan cara Collins didapatkan debit banjir rencana dengan kala ulang 20 tahunan sebesar $332 \mathrm{~m}^{3} / \mathrm{s}$ yang terjadi pada jam ke-4.

2. Berdasarkan analisis aliran rendah menggunakan model HSS Gama I dan HS Gama II dapat disimpulkan bahwa pada saat musim kemarau masih tersedia aliran sungai yang cukup untuk dapat memenuhi kebutuhan air baik untuk irigasi maupun perikanan. Dari 
analisis perhitungan HSS Gama I didapatkan nilai debit puncak sebesar 2,59 $\mathrm{m}^{3} / \mathrm{dt}$ dengan waktu puncak 1,61 jam. Sedangkan dari analisis HS Gama II didapatkan tingkat kesalahan yang terjadi dari nilai root mean square sebesar 2,5712 dan volume errornya sebesar $15,5392 \%$.

3. Analisis yang dihasilkan baik berupa aliran puncak maupun aliran rendah masih merupakan informasi awal yang harus dianalisis lagi sebelum dapat digunakan dalam perancangan bangunan-bangunan hidraulik maupun analisis ketersediaan air.

\section{Daftar Pustaka}

Hestin Mulyandari, 2011, Upaya Pengelolaan Lahan Bangunan Pada bantaran Sungai Berbasis Lingkungan Di Kabupaten Sleman DIY, Jurnal Teknik Sipil dan Perencanaan Universitas Negeri Semarang, Edisi No. 1 Vol.13, Januari 2011, Semarang.

JB. Satrio Nugroho, 2013, Upaya Menjaga Identitas Kota Yogyakarta, Intisari-Online.com, Jakarta.

RJ. Kodoatie \& Roestam S, 2010, Tata Ruang Air, Penerbit Andi, Yogyakarta.

Rahmat Jayadi, 2000, Hidrologi I, Pengenalan Hidrologi, UGM, Yogyakarta.

Sri Harto Br., 2000, Hidrologi, Teori, Masalah, Penyelesaian, Nafiri, Yogyakarta.

Supriharyono, 2002, Intisari Materi Kuliah Metodologi Penelitian, Program Pasca Sarjana Magister Teknik Sipil Universitas Diponegoro, Semarang. 
